\title{
Impacts of Training on Knowledge Dissemination and Application among Academics in Malaysian Institutions of Higher Education
}

\author{
Mohd Taib Dora (Corresponding author) \\ Centre for Languages and Human Development, University Technical Malaysia, Melaka \\ Hang Tuah Jaya, 76100 Durian Tunggal, Melaka, Malaysia \\ Tel: 60-12-603-3700 E-mail: mohdtaib@utem.edu.my \\ Hanipah Hussin \\ Centre for Languages and Human Development, University Technical Malaysia, Melaka \\ Hang Tuah Jaya, 76100 Durian Tunggal, Melaka, Malaysia \\ Tel: 60-17-601-3196 E-mail: hanipah@utem.edu.my
}

Safiah Sidek

Centre for Languages and Human Development, University Technical Malaysia, Melaka

Hang Tuah Jaya, 76100 Durian Tunggal, Melaka, Malaysia

Tel: 60-13-630-6034 E-mail: safiahsidek@utem.edu.my

Received: May 26, 2011

Accepted: July 28, 2011 Published: January 1, 2012

doi:10.5539/ass.v8n1p146

URL: http://dx.doi.org/10.5539/ass.v8n1p146

\begin{abstract}
This paper explores the linkage of knowledge dissemination and the application of new knowledge in teaching and learning practices. A survey data were collected from 519 academics from all the Malaysian public and private institutions of higher learning (IHLs) during the teaching and learning trainings offered by the Academy of Leadership in Higher Education Malaysia, known as the Akademi Kepimpinan Pengajian Tinggi Malaysia $(A K E P T)$. Three out of ten behavioral actions were found to have a significant change in behaviors at the workplace: keep-up with the institutional change process, $\mathrm{p}=0.037$, involvement in departmental change, $\mathrm{p}=0.027$ and confidence in decision-making, $\mathrm{p}=0.037$. The seven insignificant behavioral actions were asking peers and colleagues for suggestions, involvement of colleagues in the change process, reluctance in making decisions, holding group meeting, taking time to transform plan into action, and taking time to reflect the consequences of making decisions. These findings raise awareness and provide initial guidelines for AKEPT to develop appropriate strategies to ensure that the knowledge dissemination processes lead to the application of new knowledge. Further exploration of the formulation of comprehensive strategies to properly implement and manage the knowledge dissemination processes among the academics was also suggested. It is also one of the initial studies that highlight the linkages between AKEPT's Training Centre and the local teaching and learning training centre. It opens up new lines of future research possibilities on the provision of centralized professional development training programs that facilitate the application of new knowledge at the local teaching and learning context.
\end{abstract}

Keywords: Knowledge dissemination processes, Knowledge application, Perceived competence, AKEPT training programs

\section{Introduction}

In the higher education sector, the rapid expansion of knowledge makes regular training and skills updating essential for the academics that have significant roles in developing graduates for the global knowledge economy. In this case, the government and institutions of higher learning (IHLs) provide various professional development training programs to disseminate new and innovative knowledge and skills in teaching and learning for the 
academics. The effectiveness of the training programs are generally measured based on the feedback received from the participants' satisfaction of the learning experience(Sullivan \& Haley, 2009). This information is then used to improve the delivery of future programs. However, the impact of the knowledge dissemination on the academics' everyday teaching practices at the faculty level has been largely ignored. Thus, the purpose of this study was to measure the relationship between the knowledge dissemination and application at the workplace among academics in the public and private higher education institutions in Malaysia. In this case, it is not the researchers' intention to examine the content of the training programs rather it is to fill the existing vacuum between the transition of knowledge disseminated during the training programs and the application of knowledge in the local teaching and learning contexts.

For the purpose of this study, professional development programs offered by the Academy of Leadership in Higher Education Malaysia, commonly known as the Akademi Kepimpinan Pengajian Tinggi (AKEPT) was selected. Pertaining to the Malaysian Higher Education transformation plan 2007-2015, the Centre for Teaching and Learning at AKEPT is responsible to develop leadership in teaching and learning of higher education among the academics both in Malaysia's public and private IHLs. The professional development training programs offered by AKEPT cater several aspects, such as describing the role of peers and colleagues and examining the supports academics give to each other. Further, considering that re-training and developing scholarship of academics are among the priorities of any university systems, AKEPT caters how academics' work are recognized, appraised and rewarded and how well the academics' professional development needs are being addressed. Finally, it provides insights into the beliefs and attitudes about teaching and learning that academics bring into the classroom and the pedagogical practices that they adopt.

\section{Literature Review}

\subsection{Knowledge Dissemination and Learning Organization}

The theory of knowledge dissemination is based on knowledge creation, which is underpinned by the learning theories advocated by David Kolb, Reg Revans, Chris Argyris, and Jean Piaget (Note 1). It is also related to the concept of learning organization(Argyris \& Schon, 1978; Senge, 1990), whereby knowledge creation is embedded into everyday activities of the organization. It is now well understood that learning from experience takes place in an ongoing cycle(Kolb, 1984). For example, people may take action, observe and reflect upon the result (reflecting), draw conclusions (Abstracting/Connecting), choose a new action to execute and learn from (deciding), and then move back to the action stage. There are many individual "wheels of learning". Hutchinson and Huberman (cited in Graham et al., 2006) defined dissemination as the transfer of knowledge within and across settings, with the expectations that the knowledge will be used conceptually and instrumentally". The knowledge dissemination process that results in the application of knowledge is crucial for the facilitation of a transformational leadership in teaching and learning in higher education. In this respect, the application of the new pedagogical content knowledge among the academics depends on the knowledge dissemination process which encompasses the creation of knowledge-rich and evidence-based education systems.

Contextualized within the rapid changes and development in the global world, this study considers the IHLs as learning organizations. Senge (1990) defines learning organizations as

...organizations where people continually expand their capacity to create the results they truly desire, where new and expansive patterns of thinking are nurtured, where collective aspiration is set free, and where people are continually learning to see the whole together(p.3).

Further, Senge (1990) highlights five principles for the transformation of innovative learning organization which are the systems thinking, personal mastery, mental models, building shared vision and team learning. In this context, the development of an innovative faculty depends on the development of systems thinking in which the dean, head of the department, senior lecturers, young lecturers, tutors, language advisors and the entire members of the faculty learn how to disseminate and share knowledge by acting as active members of a professional community. The availability of necessary information and the access to effective support systems assist them to act wisely in implementing change and innovation in teaching and learning for the transformational leadership in teaching and learning in higher education. Thus, the knowledge dissemination process within a learning organization can be enhanced through the nurturing of a 'community of practice'(Nagy \& Burch, 2009; Wenger, 1998), in which members have shared vision and understanding, and they engage in team learning within the organization.

\subsection{Knowledge Dissemination and Transformed Learning}

Underpinned by the perspectives of social cognition, learning involves a process in which information is 
processed in many ways, few of which are replicable of the original information. Vygoktsky(1978) asserts that learners achieve cognitive understanding by engaging in a dialogue and collaboration with peers or colleagues.

The knowledge dissemination and application is drawn from perspectives of constructivism. The constructivist principles, for example, underlie many of the reform-based approaches emerging in mathematics and science education, as well as in other disciplines. Some of the basic concepts of constructivism can be found in the ideas about knowledge utilization dating back to the 1970s and before; Hutchinson(September, 1995) notes that "the constructivist perspective is evident in various models of knowledge utilization including social interaction, practical discourse, two communities, technocratic counsel, and theories-in-use models" (p. 92).

The common understanding of learning is that the learner is viewed as a sponge, "soaking up" knowledge--a role that is somewhat more active than that of an empty vessel, although what the learner absorbs is taken in wholesale, without filtering or processing. A metaphor often used in this era of technology is that of the brain as a computer, which processes in an orderly, systematic fashion the information that is received from outside sources. In this analogy the learner actively does something to or with the information, which can be presumed to be altered in appearance, if not in substance, from the form in which it was originally received.

According to the constructivist principles, none of these metaphors adequately describes the ways in which we as learners process information. Constructivism presumes that new knowledge is filtered and shaped by the learner's pre-existing experience and understandings. Learners, from the youngest children to the oldest adults, are constantly seeking to make sense of the environment; to do so; we "construct" explanations that make sense based on our personal experiences. Knowing, then, "is an adaptive activity"(Von Glasersfeld, 1995, p. 7), concerned with reaching functional understandings about the various aspects of living. Taken as the advancement of understanding, the cognitive endeavor starts from what happens to be currently adopted and proceeds to integrate and organize, weed out and supplement, not in order to arrive at truth about something already made but in order to make something right--to construct something that works cognitively, that fits together and handles new cases, that may implement further inquiry and invention(Bauersfeld, 1995).

Further, Driver (1995) explains that "human beings construct models of their environment, and new experiences and information are interpreted and understood in relation to existing mental models or schemes" (p. 386). The metaphors that suggest constructivist perspectives, then, are those of building; and shaping; new structures. In writing about the impact of the learning process on the dissemination of research, Huberman(Huberman, 1990) states: Prior knowledge does not operate like a sponge, sopping up new information... Rather, prior understandings are the mold into which new information is poured, such that the new understandings may not correspond to the researcher's conception of his own study (p. 380).

From a constructivist perspective, the task of getting learners to change their pre-existing understandings begins with helping them to recognize differences. As Shapiro(1994) points out,"In order to take on a new viewpoint, one must decide to let go of an old one. There must be a reason to decide to make a shift in thinking" (p. 7). Sechrest, Becker \& Rogers (1994), in applying this understanding to the task of dissemination, note that if practitioners "are not in a state of uncertainty about a problem" (p. 187), the mere provision of information is not likely to lead to changes in behavior. Backer (1988) makes the point even more bluntly: "People and organizations develop the energy to change when faced with real pain... whether the nature of change is personal (psychotherapy) or work-related (organizational change, implementation of an innovation)" (p. 7).

\subsection{Training Evaluation Model:Kirkpatrick (1994)}

One of the widely used models to measure the impact of training is that developed by Kirkpatrick(1994). Table 1 shows an overview of the four levels of training evaluation. As shown in Table 1, the effectiveness of training programs is measured based on four levels comprising reaction, learning, behavior and results. According to this model, evaluation should always begin with level one, and then, as time and budget allows, it should move sequentially through levels two, three, and four. Information from each prior level serves as a base for the evaluation of the subsequent level. Thus, each successive level represents a more precise measure of the effectiveness of the training program, but at the same time requires a more rigorous and time-consuming analysis.

In this study, level 3 of the Kirkpatrick model is used to measure the knowledge dissemination of the knowledge acquired from the training program and the application of the knowledge to the local workplace context. Focusing on the outcomes of the program(Wells, October, 2008), level 3 measures the changes in the learners' behavior as a result of the learning experienced during the program. An evaluation at this level attempts to answer the question Are the newly acquired skills, knowledge, or attitude being used in the everyday environment of the learner? For many trainers, this level represents the truest assessment of a program's effectiveness. However, measuring at this 
level is difficult as it is often impossible to predict when the change in behavior will occur, thus requires important decisions in terms of when to evaluate, how often to evaluate, and how to evaluate.

\section{Methodology}

This paper is a part of a larger survey research investigating on the impact of professional development programs offered by AKEPT. Data for this research were derived from a survey questionnaire distributed to 519 academics participated in the AKEPT academic professional development training programs conducted between 2008 and 2009. The participants of AKEPT's training programs were academics from both the public and private IHLs. The simple comprised of five academic rankings: professor, associate professor, senior lecturer, lecturer and assistant lecturer. The questionnaires were distributed after the respondents have completed the training programs.

As shown in Table 2, there were more male $(65 \%)$ than female (35\%) respondents in this study. Further, almost $40 \%$ of the entire respondents were within the age ranged between 35- 44 years old. The data also showed that almost $49 \%$ of respondents have less than 5 years length of service. Among the five groups, the lecturers represented the largest group (46.8\%), followed by the senior lecturer (19.1\%), associated professor (13.9\%), assistant lecturer (13.1\%) and the professor (6.9\%) respectively. Irrespective of their academic ranking, these groups act as peer group in the knowledge dissemination process

To investigate the knowledge dissemination process and application resulting from the training programs, the data gathered focuses on level 3 (Changed behaviours) of Kirkpatrick's model (1994). The change behaviors of the participations were analyzed by comparing their perceived change in behavior before and after they completed the training programs. For the purpose of data triangulation, the respondents were expected to respond according to three different junctures: academics' own perceived competence; supervisor's assessment and students' assessment. Further, the participants were expected to response to ten actions used as indicators to describe the knowledge dissemination process related to their daily teaching practices. The ten items are:

- Asking peers/colleagues for ideas/suggestions;

- Keep-up with the institutional change process;

- Involvement of peers/colleagues in the change process;

- Involvement in departmental change;

- Involvement of peers/colleagues in the teaching and learning;

- Reluctance in making decisions;

- Holding group meeting;

- Confidence in decision-making;

- Taking time to transform plan into action;

- Taking time to reflect the consequences of making decisions

A descriptive statistical analysis that is the two tail t-test analysis at the $95 \%$ confidence level was used to identify the significant differences of the changes in behavior in teaching and learning before and after participating in the training programs.

The investigation of changed behavior in relation to the ten behavioral actions related to knowledge dissemination provides a platform to review the impact of these training programs on knowledge dissemination process on the application of knowledge acquired at the local faculty. This in turn can be used as guidance to develop policies for effective delivery of training programs that can facilitate the application of new knowledge for a transformational teaching and learning in Malaysian higher education institutions.

\section{Results and Discussion}

The results of the t-test statistical analysis of the ten items in the questionnaires are shown in Table 3. Based on the table, three out of the ten behavioral actions have significant values below $\mathrm{p}=0.05$. They are keeping up with the institutional change process $(\mathrm{p}=0.037)$, involvement in the departmental change $(\mathrm{p}=0.027)$ and confidence in making decision $(\mathrm{p}=0.037)$. The other seven that were found to be insignificant are asking peers/colleagues for ideas and suggestions, involvement of peers/colleagues in the change process, involvement of peers/colleagues in the teaching and learning practice, reluctance to make decision, holding group meeting, taking time to transform plan into action and taking time to reflect of the consequences of the decision-making. The rest of this section presents the discussion of these findings, starting with the significant changed behaviors and followed by 
the insignificant ones.

\subsection{Significant Changed Behaviors}

In this study, the significant changed behaviors were represented by Questions 33, 35 and 39 (See Table 3) and they are discussed below.

\subsubsection{Keep-up with the institutional change process (Question 33)}

Most of the participants stated that follow-ups were done somewhat more after the AKEPT program as compared to before it $(31 \%$; $44.68 \%)$. The results imply that training provides a better direction for participants to perform check and balance in their teaching and learning process to ensure that they are up to date with the continuous change in teaching and learning practices. In this case, productive teachers are those who can create effective learning environments to enhance student learning. They build a conducive learning climate in which students enjoy learning and can master what they are supposed to master. Teaching is looked upon as an art, and productive teachers are looked upon as artists who can motivate their students, and to nurture in them [the students] the interest to learn and find out more about the subject being taught(Biggs, 2003). Teacher effectiveness is not only reflected in the successive teaching in the classroom or the inclusion of everything outlined in the syllabus. It also encompasses the achievement to guide students through the control subjects and to raise their interest to learn more.

\subsubsection{Involvement in departmental change (Question 35)}

The participants perceived that they were given more opportunities to be involved in the departmental teaching and learning process after the AKEPT programs. In fact, the percentage of change increased from $38 \%$ to $51 \%$. This may be due to the recognition that the superiors have on the value of the knowledge and skills the participants gained from the training. In this regards, the knowledge disseminated during training can influence the changes in the departmental teaching and learning practices. This can only be done when teachers know themselves as individuals and can adapt their own unique characteristics to the elements of the situation and the context of their teaching.

\subsubsection{Confidence in decision-making (Question 39)}

Most of the participants responded that their confidence increased after the AKEPT programs somewhat more compared to before it $(45 \% ; 48 \%)$. Although this figure may be minimal, it is a step towards molding the participants to be a confident educator. The one-way dissemination of knowledge provided by a centralized body, such as AKEPT indicates the underpinning perception that the participants are empty vessels into which the knowledge is poured. Shapiro [12] notes that "despite the fact that the 'blank slate' view of the learner is not well regarded, it seen most often in school settings" (p. 8). The learning process underpinned by the notion of constructivist is not reflected in the dissemination process.

\subsection{Insignificant Changed Behaviors}

This study also identified seven insignificant changes in behavioral actions of the respondents at the local teaching and learning contexts. These are represented by questions 32, 34, 36, 37, 38, 40 and 41 (See Table 3) and they are discussed below.

\subsubsection{Asking peers/colleagues for ideas/suggestions (Question 32)}

The results show that most of the participants of the AKEPT programs responded higher percentage of no change for asking suggestion from their peers after the program $(33 \% ; 40 \%)$ as compared to before. The academics may not feel comfortable asking or sharing information. The cultural problem is in fact considered a major challenge in change management initiatives among the IHLs because many faculty members consider knowledge as proprietary and something that is not shared freely (Wind \& Main, 1999). On the other hand, it may also be due to the superiority in knowledge that the participants felt as compared to their peers after attending the program which inhibits them from consulting their peers. This implies that community of practice (Nagy \& Burch, 2009) in which ideas and knowledge are shared collaboratively among the academics has yet to be a common practice within the IHLs.

\subsubsection{Involvement of peer/colleagues in teaching and learning (Question 34)}

The lack of collaboration and knowledge sharing among the academics is also evident in data represented by Question 34. The results show that after the AKEPT programs, most of the participants somewhat did not consult their peers in teaching and learning as compared to before the training $(45 \% / 44.6 \%)$, but this figure is just minimal. This could be due to the confidence the participants felt after the program which may make them feel superior in knowledge as compared to their peers, thus, less consultation. On the other hand, it could also be due 
to the knowledge hoarding culture of academics (Wiig, 1999) which inhibits them from knowledge sharing.

\subsubsection{Allows peers/colleagues to be involved in the teaching and learning (Question 36)}

Most of the participants similarly projected no change, in fact more (33\%; 46\%) when asked how often they included colleagues and peers in teaching and learning process. This again could be due to the confidence the participants felt after the program which may make them feel superior in knowledge as compared to their peers, thus, less consultation. On the other hand, it could also be due to the knowledge hoarding culture of academics (Wiig, 1999) which inhibits them from knowledge sharing.

\subsubsection{Reluctance in making decisions (Question 37)}

Most of the participants projected higher no change before the AKEPT training compared to after $(42 \%$; $36 \%)$ for this question. This could be due to the benefits that are derived from the training that influence them not to procrastinate teaching and/or to participate in research activities.

\subsubsection{Holding group meeting (Question 38)}

For this question, most of the participants projected higher no change before the AKEPT training compared to after $(29 \% ; 53 \%)$. This could be due to the fact that the training make them visionary leaders on their own and consultation with peers may be seen as waste of time when they could figure out problems by themselves. However, there is a negative connotation to this, in that it could be viewed that some faculty members view knowledge as a possible source of differentiation, and thus defer sharing certain aspects of their knowledge. Unfortunately, however, when knowledge is viewed as a source of power it acts as a "separator" between the haves and the have-nots (Wiig, 1999) and in some cases, knowledge loss occurs.

\subsubsection{Need time to transform plan into action (Question 40)}

Most of the participants responded that they used planned approach in decision making somewhat more after the AKEPT training compared to before it $(45 \%$; $48 \%$ ). Again although this figure may be minimal, it is a step towards molding the participants to be more systematic in their teaching and learning efforts.

\subsubsection{Need more time to reflect the consequences of making decisions (Question 41)}

Most of the participants responded that they took time to evaluate their teaching decisions somewhat more (43\%; $46 \%$ ) after the AKEPT program compared to before it. This implies that the AKEPT training trains them to reflect on their teaching decisions in order to be better knowledge disseminators and to apply the knowledge at their workplace.

\section{Implications and Suggestions}

This study examined the changes in behavior in teaching and learning among academics resulting from the knowledge disseminated during the professional training programs offered by AKEPT. Level 3 of Kirkpatrick (1994) model of evaluation training programs were utilized to capture the change behavior that represents the application of new knowledge among the academics.

With regard to the implication of practice, ILHs and AKEPT generally provide education and training for academics, and at present they are deeply involved in achieving learning outcomes. The average ratings on knowledge application and dissemination in the IHLs advocate that although the academics practice the knowledge dissemination processes, it is far from satisfactory to that the knowledge is applied at the workplace. Further, changed behaviors among the academics resulting from the dissemination of knowledge somehow do not contribute to the cultivation of community of practice within the organization as ways to achieve its competitive edge. Hence, aligned with the IHLs' nature and objectives, it is timely for IHLs to institutionalize a knowledge dissemination program in order to improve all the processes. Moreover, the academics must be given proper training, and training is not possible unless the top management has formalized the knowledge dissemination program in the institution. The IHLs must not only rigorously attempt to improve its current processes, but also to innovate them (Biloslavo, 2005). This is because if knowledge dissemination processes continues to be observed moderately as done currently in the IHLs surveyed, knowledge loss may result. Knowledge loss will result in loss of the ability to efficiently make decisions, and often ability to serve customers well (Wind \& Main, 1999).

Although IHLs are regarded as independent bodies, in that they are autonomous in creating and implementing their own regulation, MOHE still plays a role as a facilitator and lead partner in enhancing the higher education network (Morshidi, 2010). As a lead partner, MOHE does not only provide strategic direction, it also offers the support necessary to ensure the success of the institutions (MOHE, 2007). Hence, the average mean values for knowledge application and dissemination implies that AKEPT has a vital role to kick start the knowledge 
management initiatives so as to enhance IHLs' competitive advantage to anticipate further changes that will require yet more redesign in the institution's forms and practices. Moreover, AKEPT has to also conduct training aiming at cultivating a work culture that nurture knowledge sharing among the academics (Fullan, 2007). Currently, this may not have been done fully or successfully given the results of this study.

While no all-encompassing theory or explanation of knowledge utilization has been described and tested, the literature includes a great deal of information that can help to strengthen dissemination efforts. Within the varied perspectives about dissemination, authors generally consider some combination of these four major elements to be explored for next future such as:

- the dissemination source; that is, the agency, organization, or individual responsible for creating the new knowledge or product, and/or for conducting dissemination activities;

- the content or message that is disseminated, that is, the new knowledge or product itself, as well as any supporting information or materials;

- the dissemination medium; that is, the ways in which the knowledge or product is described, "packaged," and transmitted; and

- the user, or intended user, of the information or product to be disseminated.

Further, it is suggested that there is a need for more research on the evaluation of training and that investigates the application of the knowledge on the teaching and learning practice. In addition, further investigation is also needed in order to find out how much the faculty can gain from their investment in the training programs. This relates to the evaluation on the level 4 of Kirkpatrick model.

\section{References}

Argyris, C. \& Schon, D. (1978). Organisational learning: A theory of action perspective. Reading, MA: Addison-Wesley.

Backer, T. E. (1988). Research utilization and managing innovation in rehabilitation organizations. Journal of Rehabilitation, 18-22.

Bauersfeld, H. (1995). The structuring of the structures: Development and function of mathematizing as a social practice. In S. Gale (Ed.), Constructivism in education (pp. 137-158). Hillsdale, NJ: Lawrence Erlbaum Associates.

Biggs, J. (2003). Teaching for quality learning at university. Maidenhead,Berkshire: Open University Press.

Biloslavo, R. (2005). Use of the knowledge managment framework as a tool for innovation capability audit. International Journal of Innovation and Learning, 2(4), 402-424. http://dx.doi.org/10.1504/IJIL.2005.006663

Driver, R. (1995). Constructivist approaches to science teaching. In S. Gale (Ed.), Constructivism in education (pp. 385-400). Hillsdale, NJ: Lawrence Erlbaum Associates.

Fullan, M. (2007). The NEW meaning of educational change (4th ed.). Amsterdam Avenue, NY: Teachers College Press.

Graham, I., Logan, J., Harrison, M., Straus, S., Tetroe, J., Caswell, W., et al. (2006). Lost in Knowledge translation: time for a map? The Journal of Continuing Education in the Health Professions, 26, 13-24. http://dx.doi.org/10.1002/chp.47

Huberman, M. (1990). Linkage between researchers and practitioners: A qualitative study. American Educational Research Journal, 363-391.

Hutchinson, J. R. (September, 1995). A multimethod analysis of knowledge use in social policy: Research use in decisions affecting the welfare of children. Science Communication, 90-106. http://dx.doi.org/10.1177/1075547095017001005

Kirkpatrick, D. (1994). Evaluating training programs: The four levels. San Francisco: Berrett-Kochler.

Kolb, D. (1984). Experiential learning. Englewood Cliffs: Prentice-Hall.

MOHE. (2007). National higher education action plan 2007-2010. Kuala Lumpur.

Morshidi, S. (2010). Strategic planning directions of Malaysia's higher education: university autonomy in the midst of political uncertainties. Higher Education, 59(461-473). http://dx.doi.org/10.1007/s10734-009-9259-0

Nagy, J. \& Burch, T. (2009). Communities of Practices in Academe (CoP-iA): understanding academic work practices to enable knowledge building capacities in corporate universities. Oxford Review of Education, 35(2), 


\section{7-247. http://dx.doi.org/10.1080/03054980902792888}

Sechrest, L., Backer, T. E. \& Rogers, E. M. (1994). Synthesis of ideas for effective dissemination. In L. Sechrest, T. Backer, E. E. M. Rogers, T. F. Campbell \& G. M. L (Eds.), Effective dissemination of clinical and health information: Conference summary (Vol. AHCPR Pub. No. 95-0015, pp. 187-196). Rockville, MD: Agency for Health Care Policy and Research.

Senge, P. (1990). The fifth discipline: The art and practice of the learning organisation. New York: Doubleday.

Shapiro, B. (1994). What children bring to light: A constructivist perspective on children's learning in science. New York: Teachers College Press.

Sullivan, L. \& Haley, K. (2009). Using a retrospective pretest to measure learning in professional development programs. Community College Journal of Research and Practice, 33, 346-362. http://dx.doi.org/10.1080/10668920802565052

Von Glasersfeld, E. (1995). Sensory experience, abstraction, and teaching. In S. Gale (Ed.), Constructivism in education (pp. 369-383). Hillsdale, NJ: Lawrence Erlbaum Associates.

Vygoktsky, L. S. (1978). Mind in society: The development of higher psychological functions. Cambridge, MA: Harvard University Press.

Wells, J. (October, 2008). How rigorous should your training evaluation be? Corrections Today, 116-118.

Wenger, L. (1998). Communities of Practice: Learning, meaning and identity. Cambridge: Cambridge University Press.

Wiig, K. (1999). Introducing knowledge managment into the enterprise. In J. Liebowitz (Ed.), Knowledge management handbook (pp. FL.3.1-3.41): CRC Press.

Wind, J. \& Main, J. (1999). Driving change. New York: The Free Press.

\section{Note}

Note 1. For more information about them, see the fifth Discipline Field (Senge,1990, p.58). Also see Organizational learning: A Theory of Action Perspective, Chris Argyris and Donald Schon (Reading, MA: Addison-Wesley1978). Experiential Learning, by David Kolb ( Englewood Cliffs, NJ: Prentice-Hall 1984). ABC of Action Learning, by R.Revans (London: Chartwell-Bratt, 1983); Action learning: New Techniques for Management, by R. Revans (London: Blond \&Briggs, 1980); and The Developmental Psychology of Jean Piaget, by John Flavell (New York:Van Nostrand Reinhold, 1963).

Table 1. The four levels of Kirkpatrick's (1997) evaluation

\begin{tabular}{|l|l|l|l|l|}
\hline Levels & $\mathbf{1}$ & $\mathbf{2}$ & $\mathbf{3}$ & $\mathbf{4}$ \\
\hline What & $\begin{array}{l}\text { Reaction: Did } \\
\text { they like it? }\end{array}$ & $\begin{array}{l}\text { Learning: What } \\
\text { knowledge or skills did } \\
\text { they retain? }\end{array}$ & $\begin{array}{l}\text { Behavior: How are } \\
\text { they performing } \\
\text { differently? }\end{array}$ & $\begin{array}{l}\text { Results: what is the } \\
\text { impact on the bottom } \\
\text { line? }\end{array}$ \\
\hline Who & Participants & Participants; trainer & $\begin{array}{l}\text { Participants, bosses, } \\
\text { subordinates, peers }\end{array}$ & $\begin{array}{l}\text { Participants, control } \\
\text { group }\end{array}$ \\
\hline When & End of Program & $\begin{array}{l}\text { During, before/after } \\
\text { program }\end{array}$ & $\begin{array}{l}\text { 3 to 6 months after } \\
\text { program completion }\end{array}$ & $\begin{array}{l}\text { After completion of } \\
\text { level 3; follow-up }\end{array}$ \\
\hline How & "Smile Sheet" & $\begin{array}{l}\text { Pre-test/post-test; skills } \\
\text { application through role } \\
\text { plays, case studies, } \\
\text { exercises }\end{array}$ & $\begin{array}{l}\text { Surveys, interviews, } \\
\text { observation, } \\
\text { performance } \\
\text { appraisal }\end{array}$ & $\begin{array}{l}\text { Cost/benefit analysis, } \\
\text { tracking, operational } \\
\text { data }\end{array}$ \\
\hline $\begin{array}{l}\text { level of } \\
\text { customers' } \\
\text { satisfaction; } \\
\text { may indicate the } \\
\text { need for revision }\end{array}$ & $\begin{array}{l}\text { Identify whether they } \\
\text { trainer has been } \\
\text { successful in the } \\
\text { delivery of course } \\
\text { content and achieving } \\
\text { program objectives }\end{array}$ & $\begin{array}{l}\text { Determine the extent } \\
\text { to which participants } \\
\text { have transferred what } \\
\text { they learned in the } \\
\text { session to the actual } \\
\text { work situation }\end{array}$ & $\begin{array}{l}\text { Determine whether the } \\
\text { benefits outweigh the } \\
\text { costs, ascertain degree } \\
\text { of contribution of } \\
\text { program to } \\
\text { organizational goals. }\end{array}$ \\
\hline
\end{tabular}


Table 2. Background of the respondents

\begin{tabular}{|l|l|l|}
\hline & Frequency & Percent (\%) \\
\hline Gender & & \\
\hline Male & 336 & 64.7 \\
\hline Female & 183 & 35.3 \\
\hline Age group (years ) & & \\
\hline$<25$ & 48 & 9.3 \\
\hline $25-34$ & 105 & 20.2 \\
\hline $35-44$ & 207 & 39.9 \\
\hline $45-54$ & 108 & 20.8 \\
\hline 55 and above & 51 & 9.8 \\
\hline Rank of Colleagues & & \\
\hline Assistant Lecturer & 69 & 13.3 \\
\hline Lecturer & 243 & 46.8 \\
\hline Senior Lecturer & 99 & 19.1 \\
\hline Associate Professor & 72 & 13.9 \\
\hline Professor & 36 & 6.9 \\
\hline Length of service (years) & & \\
\hline $0-5$ & 255 & 49.1 \\
\hline $6-10$ & 105 & 20.2 \\
\hline $11-20$ & 72 & 13.9 \\
\hline $21-30$ & 60 & 11.6 \\
\hline 31 and above & 27 & 5.2 \\
\hline & & \\
\hline
\end{tabular}


Table 3. Knowledge Dissemination Process and Application

\begin{tabular}{|c|c|c|c|c|c|c|c|c|}
\hline \multirow{4}{*}{$\begin{array}{l}\text { ISSUES IN } \\
\text { EFFECTIVE } \\
\text { DISSEMINATION } \\
\text { Before and After } \\
\text { Training } \\
\text { (Change of } \\
\text { Performances Behaviour } \\
\text { in T\&L) }\end{array}$} & \multicolumn{3}{|c|}{ DATA TRIANGULATION } & & & & & \\
\hline & \multirow{3}{*}{$\begin{array}{l}\text { Level } 3 \\
\text { Perceive } \\
\text { d on own } \\
\text { T\&L } \\
\text { before } \\
\text { and after } \\
\text { Training }\end{array}$} & \multirow{3}{*}{$\begin{array}{l}\text { Level } 3 \\
\text { Supervisor } \\
\text { Assessmen } \\
\mathrm{t} \text { on your } \\
\mathrm{T} \& \mathrm{~L} \\
\text { before and } \\
\text { after } \\
\text { Training } \\
\text { (Change) }\end{array}$} & \multirow{3}{*}{$\begin{array}{l}\text { Level } 3 \\
\text { Students } \\
\text { Assessm } \\
\text { ent on } \\
\text { your } \\
\text { T\&L } \\
\text { before } \\
\text { and after } \\
\text { Training } \\
\text { (Change) }\end{array}$} & \multicolumn{3}{|c|}{ Paired Differences } & \multirow[b]{3}{*}{ df } & \multirow[b]{3}{*}{$\begin{array}{l}\text { Sig. } \\
\text { (2-tailed) }\end{array}$} \\
\hline & & & & \multicolumn{3}{|c|}{$\begin{array}{l}95 \% \text { Confidence Interval of the } \\
\text { Difference }\end{array}$} & & \\
\hline & & & & Lower & Upper & $\mathrm{t}$ & & \\
\hline $\begin{array}{l}\text { 32-How often did you } \\
\text { ask your peer/ colleague } \\
\text { for suggestions or ideas } \\
\text { regarding the change in } \\
\text { teaching and learning? }\end{array}$ & $\begin{array}{l}\text { Some } \\
\text { what } \\
\text { Less } \\
(2)\end{array}$ & $\begin{array}{l}\text { Some } \\
\text { what } \\
\text { Less } \\
(2)\end{array}$ & $\begin{array}{l}\text { Some } \\
\text { what } \\
\text { Less } \\
(2)\end{array}$ & -.457 & .286 & -.461 & 46 & .647 \\
\hline $\begin{array}{l}\text { 33-Do you do more } \\
\text { follow-up to the T\&L } \\
\text { change process in your } \\
\text { institution to make sure } \\
\text { it is going in the right } \\
\text { direction? }\end{array}$ & $\begin{array}{l}\text { Much } \\
\text { more } \\
\text { Change } \\
(5)\end{array}$ & $\begin{array}{l}\text { Much } \\
\text { more } \\
\text { Change } \\
(5)\end{array}$ & $\begin{array}{l}\text { Much } \\
\text { more } \\
\text { Change } \\
(5)\end{array}$ & -.660 & -.021 & -2.143 & 46 & $\begin{array}{l}.037 \\
\mathbf{0}\end{array}$ \\
\hline $\begin{array}{l}\text { 34-How often have you } \\
\text { involved your peer/ } \\
\text { colleagues by asking } \\
\text { them for T\&L } \\
\text { suggestions or ideas? }\end{array}$ & $\begin{array}{l}\text { Some } \\
\text { what } \\
\text { Less } \\
(2)\end{array}$ & $\begin{array}{l}\text { Some } \\
\text { what } \\
\text { Less } \\
(2)\end{array}$ & $\begin{array}{l}\text { Some } \\
\text { what } \\
\text { Less } \\
(2)\end{array}$ & -.324 & .282 & -.141 & 46 & .888 \\
\hline $\begin{array}{l}\text { 35-How often did your } \\
\text { superior involve you in } \\
\text { the departmental T\&L } \\
\text { process? }\end{array}$ & $\begin{array}{l}\text { Much } \\
\text { more } \\
\text { change } \\
(5)\end{array}$ & $\begin{array}{l}\text { Much } \\
\text { more } \\
\text { change } \\
(5)\end{array}$ & $\begin{array}{l}\text { Much } \\
\text { more } \\
\text { change } \\
(5)\end{array}$ & -.600 & -.038 & -2.284 & 46 & .027 \\
\hline $\begin{array}{l}\text { 36-How often did you } \\
\text { involve peers/ } \\
\text { colleagues in the T\&L? }\end{array}$ & $\begin{array}{l}\text { Some } \\
\text { what } \\
\text { Less } \\
(2)\end{array}$ & $\begin{array}{l}\text { Some } \\
\text { what } \\
\text { Less } \\
(2) \\
\end{array}$ & $\begin{array}{l}\text { Some } \\
\text { what } \\
\text { Less } \\
(2)\end{array}$ & -.432 & .219 & -.658 & 46 & .514 \\
\hline $\begin{array}{l}\text { 37-Did you have } \\
\text { tendency to put off } \\
\text { making T\&L decisions? }\end{array}$ & $\begin{array}{l}\text { Some } \\
\text { what } \\
\text { Less } \\
(2)\end{array}$ & $\begin{array}{l}\text { Some } \\
\text { what } \\
\text { Less } \\
(2) \\
\end{array}$ & $\begin{array}{l}\text { Some } \\
\text { what } \\
\text { Less } \\
(2)\end{array}$ & -.547 & .164 & -1.086 & 46 & .283 \\
\hline $\begin{array}{l}\text { 38-Did you hold T\&L } \\
\text { group meetings with } \\
\text { peers/ colleagues? }\end{array}$ & $\begin{array}{l}\text { Some } \\
\text { what } \\
\text { more } \\
(4)\end{array}$ & $\begin{array}{l}\text { Much } \\
\text { more } \\
\text { Change } \\
(5) \\
\end{array}$ & $\begin{array}{l}\text { Some } \\
\text { what } \\
\text { Less } \\
(2)\end{array}$ & -.627 & .031 & -1.821 & 46 & .075 \\
\hline $\begin{array}{l}\text { 39-Did you have } \\
\text { confidence in the T\&L } \\
\text { decisions you made? }\end{array}$ & $\begin{array}{l}\text { Much } \\
\text { more } \\
\text { Change } \\
(5)\end{array}$ & $\begin{array}{l}\text { Much } \\
\text { more } \\
\text { Change } \\
(5)\end{array}$ & $\begin{array}{l}\text { Much } \\
\text { more } \\
\text { Change } \\
(5)\end{array}$ & -.660 & -.021 & -2.143 & 46 & .037 \\
\hline $\begin{array}{l}\text { 40-Did you use a } \\
\text { planned T\&L approach } \\
\text { in decision making } \\
\text { (taking more time to } \\
\text { define the problem to } \\
\text { develop an answer)? }\end{array}$ & $\begin{array}{l}\text { Some } \\
\text { what } \\
\text { Less } \\
(2)\end{array}$ & $\begin{array}{l}\text { Some } \\
\text { what } \\
\text { Less } \\
(2)\end{array}$ & $\begin{array}{l}\text { Some } \\
\text { what } \\
\text { Less } \\
(2)\end{array}$ & -.507 & .124 & -1.220 & 46 & .229 \\
\hline $\begin{array}{l}\text { 41-Did you take time to } \\
\text { reflect results of a T\&L } \\
\text { decision? }\end{array}$ & $\begin{array}{l}\text { Much } \\
\text { more } \\
\text { Change } \\
\text { (5) }\end{array}$ & $\begin{array}{l}\text { Some } \\
\text { what } \\
\text { Less } \\
(2) \\
\end{array}$ & $\begin{array}{l}\text { Some } \\
\text { what } \\
\text { Less } \\
(2)\end{array}$ & -.603 & .008 & -1.962 & 46 & .056 \\
\hline
\end{tabular}

